\title{
Determination of heavy metal concentrations in six species of fresh water fish sold in Quetta city, Pakistan
}

\author{
Yasmeen Malik $^{1}$, Wali Mohammad Achakzai ${ }^{1}$, Shafi Muhammad ${ }^{2 *}$, \\ Safia Mustafa ${ }^{3}$, Shagufta saddozai ${ }^{4}$, Abdul Qadir ${ }^{5}$, Nisar Ahmad ${ }^{6}$ and \\ Iftikhar Ahmed Baloch ${ }^{7}$ \\ 1. Department of Zoology, University of Balochistan, Quetta-Pakistan \\ 2. Department of Pharmacognosy, Faculty of Pharmacy and Health Sciences, University of Balochistan, Quetta- \\ Pakistan \\ 3. Department of Chemistry, University of Balochistan, Quetta-Pakistan \\ 4. Department of Zoology, SBK Women's University Quetta-Pakistan \\ 5. Department of Pharmaceutics, Faculty of Pharmacy and Health Sciences, University of Balochistan, Quetta- \\ Pakistan \\ 6. Department Pharmaceutical Chemistry, Faculty of Pharmacy and Health Sciences, University of Balochistan, \\ Quetta-Pakistan \\ 7. Department of Botany, University of Balochistan, Quetta-Pakistan \\ *Corresponding author's email: Pharmacognosist59@yahoo.com
}

Citation

Yasmeen Malik, Wali Mohammad Achakzai, Shafi Muhammad, Safia Mustafa, Shagufta saddozai, Abdul Qadir, Nisar Ahmad and Iftikhar Ahmed Baloch.. Determination of heavy metal concentrations in six species of fresh water fish sold in Quetta city, Pakistan. Pure and Applied Biology. Vol. 6, Issue 1, pp79-86. http://dx.doi.org/10.19045/bspab.2016.50169

\begin{tabular}{llll}
\hline \hline Received: 15/11/2016 & Revised: 17/12/2016 & Accepted: 22/12/2016 & Online First: 29/12/2016 \\
\hline \hline
\end{tabular}

\section{Abstract}

Current study was carried out to determine heavy metals in six species of fish i.e. Oreochromis mosambicus, Cyprinus carpio, Tor putitora, Cirrhinus mrigala, Labeo rohita and Ctenopharyngodon idella, belonging to class Cyprinidae, collected from the fish markets of Quetta city, Balochistan. Concentrations of Iron (Fe), Manganese (Mn), Zinc ( $\mathrm{Zn})$, Copper ( $\mathrm{Cu}$ ), Cadmium $(\mathrm{Cd})$ Lead $(\mathrm{Pb})$, Chromium $(\mathrm{Cr})$ and Nickle $(\mathrm{Ni})$ were determined in Liver, Heart, Gills and Muscles of selected species by using atomic absorption spectrophotometer. Concentration of Fe was higher than the World Health Organization (WHO) limits in all species except Ctenopharyngodon idella. Concentration of $\mathrm{Zn}$ was within the limits except Cyprinus carpio. Concentration of $\mathrm{Mn}, \mathrm{Cu}, \mathrm{Cd}$ and $\mathrm{Pb}$ were below the limits set by WHO. $\mathrm{Cr}$ and $\mathrm{Ni}$ were not detected in any species. The concentrations of heavy metals in edible part (muscles) of all species were below the WHO limits. So, current study reveals that the fish of selected species are safe for human consumption.

Keywords: Atomic absorption spectrophotometer; Cyprinidae; Heavy metals; Quetta; WHO

\section{Introduction}

Fish are an important aquatic source of food, which are found in aquatic ecosystems. Fish are also used as a good indicator of heavy metals and various other elemental contaminations [1]. Aquaculture is one of the newest fields of fisheries for food production [2]. As a nutrition, fish is very 
important for human beings because it contains not only proteins but also omega-3 polyunsaturated fatty acids of two types, Docosahexaenoic acid (DHA) and Eicosapentaenoic acid (EPA). For regular development, Omega-3 (n-3) fatty acids are very essential, where they prevent preterm delivery, stroke and heart disease by reducing cholesterol levels [3]. Fish also perform an essential role in human health because they contain minerals and vitamins [4].

Fish are considered to be nutritive, due to the presence of lipid soluble vitamins, important proteins and polyunsaturated fatty acids. From marine and freshwater environments, fish usually accumulate pollutants, which may be harmful for human health, and therefore, this information is essential for safety. Because of their accumulative behavior and toxicity, metals released into the oceanic water can destruct both marine ecosystems and diversity of marine life [5]. The primary route for heavy metal consumption or dissolved pollutants in fish is via their gills or through ionic interchange across the membranes or transport across biological membranes. The second route is through consumption of sediment particles or food which is then transported through the mouth [6]. Heavy metals like manganese, zinc, nickel, iron, copper and chromium are essential and vital elements, subsequently they play a significant function in organic or biotic body systems. Heavy metals are essential for the regular metabolic activity in fish and are found in the aquatic food, in different sediments and water [7]. Lead, Arsenic and Cadmium are termed as non-essential elements, and are poisonous even in minute quantities [8]. Fishes play a vital role in aquatic food web and chain which are very sensitive to pollution. Fishes mostly inhabit freshwaters such as lakes, streams, and rivers. If these water systems are polluted with trace and heavy metals, fishes migrate to the areas where there is minimum contamination in order to survive [1].

Quetta is the Capital of Balochistan [9]. District Quetta is divided into rural and urban population. According to the fishermen, fish available in Quetta mostly come from Karachi, Sukkur, Naseerabad and Jafarabad. Some of them are farmed fishes, but most (about 70\%) are from Indus River. Fishes are available in Quetta market throughout the year but people mostly use fish from September to April because in the winter season the fish production increases and Quetta experiences severe winters, consumption of fish increases in these days.

\section{Materials and methods}

\section{Fish availability}

The present study was conducted on freshwater fish which were collected from local fish market of Quetta city. It is worth noting that a wide variety of edible fish are available in Quetta city which are transported from different areas of Pakistan, as mentioned earlier, and are available throughout the year (except in June and July when fishing is prohibited).

\section{Fish sample collection}

Total 18 (three from each species) commercial fish were purchased from local fish market of Quetta. Six species i.e. Labeo rohita (Rohu), Cirrhinus marigala (Mori), Cyprinus carpio (Gulfam), Tor putitora (Mahaseer), Ctenopharyngodon idella (Grass carp) and Oreochromis mosambicus (Tilapia, Daya) were selected. The fish samples were kept in cool ice boxes and moved to the Zoology Department, University of Balochistan.

\section{Identification of fish species}

Fish were identified to confirm the selected species through illustrations and using keys provided by Talwar and Jhingaran [10], and Jayaram [11]. 


\section{Preparation of sampling for heavy metal detection}

In the laboratory fish were dissected by using plastic scissors and knives to separate the organs (liver, heart, gill, and muscles). These samples were dried separately in the oven at $105^{\circ} \mathrm{C}$ for 3 hours. The dried tissues of fish were collected and reduced into powder form by using pestle and mortar. $1 \mathrm{gm}$ powdered samples were taken in a 100 $\mathrm{ml}$ beaker and $10 \mathrm{ml}$ of Nitric acid (67\%) was added. Afterwards, the samples were kept in a fume hood for digestion at room temperature for 24 hours.

Then $4 \mathrm{ml}$ perchloric acid $\left(\mathrm{HClO}_{4}\right)$ was added to the samples and kept at $60{ }^{\circ} \mathrm{C}$ on a hot plate until samples were reduced to $1 \mathrm{ml}$ residue. The residue was cooled and diluted with deionized water up to $50 \mathrm{ml}$ and then filtered through whatman (41) filter paper [12]. To make the volume up to hundred $\mathrm{ml}$ (stock solution), appropriate de-ionized water was added and kept in volumetric flask until analyzed by Atomic absorption spectrophotometer (Perkin- Analyst 800 JAPAN) [13-15].

\section{Statistical analysis}

The results obtained were subjected to statistical evaluation. The evaluated parameters were mean, standard deviation (SD) and standard error mean (SEM) by using SPSS (16) software.

\section{Results}

The results indicate the differences in sensitivity to metals among the different organs of same fish.

\section{Oreochromis mosambicus (Tilapia)}

The concentration of $\mathrm{Fe}$ was higher in the liver as compared to the limits set by WHO. $\mathrm{Mn}, \mathrm{Cd}, \mathrm{Zn}$ and $\mathrm{Cu}$ were detected in all organs except $\mathrm{Cu}$ which was not detected in muscles and their values were below the limits of $\mathrm{WHO} . \mathrm{Pb}$ was found only in the gills and its value was below the WHO limits (Table 1).

Table 1. Concentration of trace and heavy metals in the Oreochromis mossambicus

\begin{tabular}{|l|l|l|l|l|l|l|l|l|}
\hline Metals & Fe & Mn & Zn & Cu & Cd & Pb & Cr & Ni \\
\hline Liver & $2.156 \pm$ & $0.067 \pm$ & $0.635 \pm$ & $0.025 \pm$ & $0.022 \pm$ & ND & ND & ND \\
(ppm + SEM) & 0.001155 & 0.000577 & 0.000577 & 0.000577 & 0.006351 & & & \\
\hline Heart & $0.27 \pm$ & $0.065 \pm$ & $0.493 \pm$ & $0.026 \pm$ & $0.013 \pm$ & ND & ND & ND \\
(ppm +SEM) & 0.005774 & 0.000577 & 0.000577 & 0.000577 & 0.000577 & & & \\
\hline Gills & $0.638 \pm$ & $0.126 \pm$ & $1.263 \pm$ & $0.009 \pm$ & $0.052 \pm$ & $0.047 \pm$ & ND & ND \\
(ppm +SEM) & 0.000577 & 0.000577 & 0.000577 & 0.001155 & 0.000577 & 0.000577 & & \\
\hline $\begin{array}{l}\text { Muscle } \\
\text { (ppm +SEM) }\end{array}$ & $0.065 \pm$ & $0.064 \pm$ & $0.408 \pm$ & ND & $0.018 \pm$ & ND & ND & ND \\
\hline $\begin{array}{l}\text { WHO Limit } \\
\text { (ppm) }\end{array}$ & 1 & 2.5 & 5 & 0.5 & 0.2 & & & \\
\hline
\end{tabular}

Values are Mean \pm SEM of the concentration of heavy metals in Oreochromis mossambicus, ND= not detected, ppm=part per million.

\section{Cyprinus carpio (Gulfam)}

The highest mean concentration of $\mathrm{Fe}$ was detected in the liver. The highest concentration of $\mathrm{Zn}$ was found in the gills, which was above the WHO limit.
Concentration of $\mathrm{Pb}$ and $\mathrm{Mn}$ were below the limits of WHO. $\mathrm{Cu}$ was found in liver only. $\mathrm{Ni}$ and $\mathrm{Pd}$ were not reported in any selected organ (Table 2). 
Table 2. Concentration of trace and heavy metals in the Cyprinus carpio

\begin{tabular}{|l|l|l|l|l|l|l|l|l|}
\hline Metals & Fe & Mn & Zn & Cu & Cd & Cr & Ni & Pb \\
\hline Liver & $1.036 \pm$ & $0.058 \pm$ & $1.806 \pm$ & $0.063 \pm$ & $0.029 \pm$ & ND & ND & ND \\
(ppm \pm SEM) & 0.000577 & 0.000577 & 0.000577 & 0.000577 & 0.001155 & & & \\
\hline Heart & $0.191 \pm$ & $0.075 \pm$ & $0.328 \pm$ & ND & $0.033 \pm$ & ND & ND & ND \\
(ppm + SEM) & 0.001155 & 0.000577 & 0.000577 & & 0.000577 & & & \\
\hline Gills & $0.572 \pm$ & $0.14 \pm$ & $10.92 \pm$ & ND & $0.077 \pm$ & ND & ND & ND \\
(ppm +SEM) & 0.000577 & 0.005774 & 0.017321 & & 0.001155 & & & \\
\hline Muscle & $0.052 \pm$ & $0.052 \pm$ & $0.262 \pm$ & ND & $0.026 \pm$ & ND & ND & ND \\
(ppm + SEM) & 0.001732 & 0.001732 & 0.000577 & & 0.000577 & & & \\
\hline WHO Limit (ppm) & 1 & 2.5 & 5 & 0.5 & 0.2 & 0.5 & 0.5 & 1.5 \\
\hline
\end{tabular}

Values are Mean \pm SEM of the concentration of heavy metals in Cyprinus carpio, ND= not detected, ppm=part per million.

\section{Tor putitora (mahaseer)}

Iron $(\mathrm{Fe})$ was reported in all the organs of fish except muscles. The highest concentration of $\mathrm{Fe}$ was in gills. Fe was detected in liver and heart. $\mathrm{Zn}, \mathrm{Mn}$ and $\mathrm{Cu}$ were detected in the entire selected organ and found within the WHO limits. Cd and Pd were detected in all selected organs and their concentration was below the limits suggested by WHO. $\mathrm{Ni}$ and $\mathrm{Cr}$ were not detected in any organ (Table 3 ).

Table 3. Concentration of trace and heavy metals in Tor putitora

\begin{tabular}{|l|l|l|l|l|l|l|l|l|}
\hline Metal & Fe & Mn & Zn & Cu & Cd & Pb & Cr & Ni \\
\hline Liver & $1.252 \pm$ & $0.126 \pm$ & $0.971 \pm$ & $0.091 \pm$ & $0.037 \pm$ & $0.164 \pm$ & ND & ND \\
$(\mathrm{ppm} \pm$ SEM) & 0.001 & 0.001 & 0.001 & 0.002 & 0.001 & 0.001 & & \\
\hline Heart & $1.445 \pm$ & $0.364 \pm$ & $1.268 \pm$ & $0.103 \pm$ & $0.041 \pm$ & $0.195 \pm$ & ND & ND \\
(ppm \pm SEM) & 0.000577 & 0.000577 & 0.000577 & 0.000577 & 0.000577 & 0.000577 & & \\
\hline Gills & $4.211 \pm$ & $1.437 \pm$ & $1.701 \pm$ & $0.052 \pm$ & $0.052 \pm$ & $0.454 \pm$ & ND & ND \\
(ppm \pm SEM) & 0.000577 & 0.000577 & 0.000577 & 0.000577 & 0.000577 & 0.000577 & & \\
\hline Muscle & $0.086 \pm$ & $0.09 \pm$ & $0.214 \pm$ & ND & $0.04 \pm$ & $0.512 \pm$ & ND & ND \\
(ppm \pm SEM) & 0.000577 & 0.00577 & 0.000577 & & 0.005774 & 0.000577 & & \\
\hline WHO Limit & 1 & 2.5 & 5 & 0.5 & 0.2 & 1.5 & 0.5 & 0.5 \\
(ppm) & & & & & & & & \\
\hline
\end{tabular}

Values are Mean \pm SEM of the concentration of heavy metals in Tor putitora, ND= not detected, $\mathrm{ppm}=\mathrm{part}$ per million

\section{Cirrhinus mrigala (mori)}

Highest quantity of $\mathrm{Fe}$ was found in the heart and its value was above the recommended WHO limits (1ppm). Cu was reported in all selected organs except in muscles. Cd, Mn, Zn were reported in all the samples and found below the recommended WHO limits. Ni was reported only in gills of the fish. $\mathrm{Cr}$ and $\mathrm{Pb}$ were not found in any of the selected organs (Table 4).

Table 4. Concentration of trace and heavy metals in Cirrhinus mrigala

\begin{tabular}{|l|l|l|l|l|l|l|l|l|}
\hline Metal & Fe & Mn & Zn & $\mathbf{C u}$ & $\mathbf{C d}$ & $\mathbf{N i}$ & $\mathbf{C r}$ & $\mathbf{P b}$ \\
\hline Liver & $0.999 \pm$ & $0.112 \pm$ & $0.895 \pm$ & $0.197 \pm$ & $0.045 \pm$ & & ND & ND \\
$(\mathrm{ppm} \pm$ SEM) & 0.000577 & 0.000577 & 0.000577 & 0.000577 & 0.000577 & ND & & \\
\hline Heart & $1.339 \pm$ & $0.218 \pm$ & $0.442 \pm$ & $0.132 \pm$ & $0.053 \pm$ & & & \\
$(\mathrm{ppm} \pm$ SEM) & 0.000577 & 0.000577 & 0.000577 & 0.000577 & 0.000577 & ND & ND & ND \\
\hline Gills & $0.711 \pm$ & $0.338 \pm$ & $3.284 \pm$ & $0.103 \pm$ & $0.057 \pm$ & $0.001 \pm$ & ND & ND \\
(ppm \pm SEM) & 0.000577 & 0.000577 & 0.000577 & 0.000577 & 0.000577 & 0.000577 & & \\
\hline Muscle & $0.101 \pm$ & $0.188 \pm$ & $0.262 \pm$ & ND & $0.051 \pm$ & ND & ND & ND \\
(ppm + SEM) & 0.000577 & 0.000577 & 0.000577 & & 0.000577 & & & \\
\hline WHO Limit (ppm) & 1 & 2.5 & 5 & 0.5 & 0.2 & 0.5 & 0.5 & 1.5 \\
\hline
\end{tabular}

Values are Mean \pm SEM of the concentration of metals in Cirrhinus mrigala, $\mathrm{ND}=$ not detected, $\mathrm{ppm}=\mathrm{part}$ per million 


\section{Labeo rohita (rohu)}

Highest concentration of Fe was in the gills and it was above the WHO limit. Zn, Mn, $\mathrm{Cd}, \mathrm{Cu}$ and $\mathrm{Pd}$ were detected in all organs and their concentrations were below the limits set by WHO. $\mathrm{Cr}$ and $\mathrm{Ni}$ were not found in any organs (Table 5).

Table 5. Concentration of trace and heavy metals in Labeo rohita

\begin{tabular}{|l|l|l|l|l|l|l|l|l|}
\hline Metal & Fe & Mn & Zn & $\mathbf{C u}$ & $\mathbf{C d}$ & $\mathbf{P b}$ & $\mathbf{C r}$ & $\mathbf{N i}$ \\
\hline Liver & $0.204 \pm$ & $0.112 \pm$ & $1.365 \pm$ & $0.305 \pm$ & $0.059 \pm$ & $0.568 \pm$ & ND & ND \\
$(\mathrm{ppm}+$ SEM) & 0.000577 & 0.000577 & 0.000577 & 0.000577 & 0.000577 & 0.000577 & & \\
\hline Heart & $0.436 \pm$ & $0.135 \pm$ & $0.816 \pm$ & $0.078 \pm$ & $0.052 \pm$ & $0.741 \pm$ & ND & ND \\
$(\mathrm{ppm}+$ SEM) & 0.000577 & 0.000577 & 0.000577 & 0.000577 & 0.000577 & 0.000577 & & \\
\hline Gills & $5.701 \pm$ & $1.365 \pm$ & $3.726 \pm$ & $0.082 \pm$ & $0.081 \pm$ & $0.928 \pm$ & ND & ND \\
$(\mathrm{ppm}+$ SEM) & 0.000577 & 0.000577 & 0.000577 & 0.000577 & 0.000577 & 0.000577 & & \\
\hline $\begin{array}{l}\text { Muscle } \\
(\mathrm{ppm}+\text { SEM) }\end{array}$ & $0.353 \pm$ & $0.113 \pm$ & $0.666 \pm$ & $\mathrm{ND}$ & $0.06 \pm$ & $0.412 \pm$ & $\mathrm{ND}$ & $\mathrm{ND}$ \\
\hline $\begin{array}{l}\text { WHO Limit } \\
(\mathrm{ppm})\end{array}$ & 0.000577 & 0.000577 & 0.00057 & & 0.005774 & 0.000577 & & \\
\hline
\end{tabular}

Values are Mean \pm SEM of the concentration of heavy metals in Labeo rohita, $\mathrm{ND}=$ not detected, ppm=part per million

\section{Ctenopharyngodon idella (Grass carp)}

$\mathrm{Fe}, \mathrm{Mn}, \mathrm{Cd}$ and $\mathrm{Zn}$ were detected in all organs and the values were below the limits of WHO. $\mathrm{Cu}$ was only detected in the liver and its concentration was below the WHO limits. $\mathrm{Cr}$ and $\mathrm{Ni}$ were not found in any organ. $\mathrm{Pb}$ was only found in liver and its concentration was within the WHO limits (Table 6).

Table 6. Concentration of trace and heavy metals in Ctenopharyngodon idella

\begin{tabular}{|l|l|l|l|l|l|l|l|l|}
\hline Metal & Fe & Mn & Zn & Cu & Cd & Pb & Cr & Ni \\
\hline Liver & $0.8 \pm$ & $0.267 \pm$ & $0.98 \pm$ & $0.001 \pm$ & $0.067 \pm$ & ND & ND & ND \\
(ppm + SEM) & 0.057735 & 0.000577 & 0.005774 & 0.000577 & 0.000577 & & & \\
\hline Heart & $0.191 \pm$ & $0.127 \pm$ & $0.581 \pm$ & ND & $0.07 \pm$ & $0.042 \pm$ & ND & ND \\
(ppm + SEM) & 0.000577 & 0.000577 & 0.000577 & & 0.005774 & 0.000577 & & \\
\hline Gills & $0.671 \pm$ & $0.301 \pm$ & $1.91 \pm$ & & $0.086 \pm$ & $0.003 \pm$ & ND & ND \\
(ppm + SEM) & 0.000577 & 0.000577 & 0.005774 & ND & 0.000577 & 0.000577 & & \\
\hline Muscle & $0.034 \pm$ & $0.074 \pm$ & $0.17 \pm$ & & $0.075 \pm$ & $0.076 \pm$ & & \\
(ppm + SEM) & 0.000577 & 0.000577 & 0.005774 & ND & 0.000577 & 0.000577 & ND & ND \\
\hline WHO Limit (ppm) & 1 & 2.5 & 5 & 0.5 & 0.2 & 1.5 & 0.5 & 0.5 \\
\hline
\end{tabular}

Values are Mean \pm SEM of the concentration of heavy metals in Ctenopharyngodon idella, ND= not detected, $\mathrm{ppm}=$ part per million

\section{Discussion}

Since ages, fishes have been used by humans and animals as a primary source of food. Fishes contain all those nutrients in their organs which are essential for our growth. Due to the presence of various minerals and metals, fishes are an excellent nutritional source [16]. The study showed a varied tendency of the different organs of the fish to accumulate heavy and trace metals. It was known through the present study that different organs of the fish stored metals in different concentrations depending on the variety and species of the fish, and this was due to the different feeding habits, behaviors, and living [17, 18]. $\mathrm{Mn}, \mathrm{Zn}, \mathrm{Cu}$ and $\mathrm{Fe}$ are counted in the group of essential and trace metals, and are compulsory for 
normal functioning of many metalcontaining enzymes and maintaining cellular function. Depending on their absorption, they may leave beneficial or harmful impact on aquatic animals i.e. fish [19]. Liver of the fish contained highest concentrations of heavy metals [21] [20]. Liver plays a significant function in detoxification and breakdown of metals. Metallothioneins which are mostly found in the liver of fish are responsible for storing and detoxifying of metals in fish [22]. Muscles of the fish were found the least metal storing organs according to the results of the present study. Accumulation of some of the metals like $\mathrm{Cu}$, $\mathrm{Mn}, \mathrm{Fe}$, and $\mathrm{Zn}$ were found mainly in the liver and gills of the selected species. On the other hand, $\mathrm{Pb}$ and $\mathrm{Cd}$ were found mostly in the heart and the gills. The accumulation pattern of $\mathrm{Pb}$ and $\mathrm{Cd}$ differed between species where the concentration of metals fluctuated between the gills and liver. The assembling of essential and trace metals in the liver is related to the function in metabolism [23]. Fe is the main constituent of protein in hemoglobin, mainly deposited in livers of fish and reprocessed in the formation of RBCs. Higher accumulation of $\mathrm{Fe}$ in the livers of fish shows its significant physiological and metabolic role in the fish [24]. In present study iron was found in highest concentration in liver and heart of the fish. Presence of heavy metals in fishes potentially affects fish consumers. These heavy metals accumulate in fish tissues and lead to serious health problems. Because of this, the problem of trace and heavy metal pollution in fish has received great attention [25]. Heavy metals cause suppression of immune system, carcinogenesis and mutagenesis [26]. The toxicity of $\mathrm{Cd}$ and $\mathrm{Pb}$ is well known [27]. $\mathrm{Cd}$ is not considered as essential element for humans and known to be an element harmful for the organs such as liver, lungs and kidneys [28]. It is known that $\mathrm{Cd}$ accumulates in both kidneys and liver. Half-life of this heavy metal in human body is between 10-40 years [29]. Exposure to high concentrations of $\mathrm{Cd}$ can affect immune and central nervous system, and may cause fertility disorders and different types of cancers. $\mathrm{Pb}$ affects normal growth and causes intellectual retardation in children. In adults it causes hypertension and cardiac diseases [30]. Copper is an essential metal which produces lethal effects such as liver cirrhosis and dermatitis when taken in higher amounts [31]. At low concentrations, Copper causes vomiting, diarrhea, nausea, and headaches. At excessive levels of deposition, copper affects the proper functioning of kidneys and liver [32, 33].

In present study $\mathrm{Pb}$ was detected in Oreochromis mosambicus, Tor putitora, Labeo rohita and Ctenopharyngodon idella whereas $\mathrm{Cd}$ was detected in all the samples, and their concentrations were below the WHO limits. $\mathrm{Pb}$ was not detected in Cirrhinus mrigala and Cyprinus carpio. $\mathrm{Ni}$ and $\mathrm{Cr}$ were not detected in any sample. Current study reveals that the concentration of $\mathrm{Pb}$ and $\mathrm{Cr}$ were below the limits set by WHO, so these species are safe for human consumption.

\section{Conclusion}

It is deduced from the present study that the monitoring of the concentration of heavy metals in different tissues of fish is necessary. As it was observed that the concentration of heavy metals in edible part (muscles) was within the recommended limits of WHO, the higher concentration in nonedible parts should also be monitored in order to protect the aquatic ecosystems and to reduce its indirect impact on human health.

\section{Authors' contributions}

Conceived and designed the experiments: Wali Mohammad Achakzai, Shafi Muhammad, Shagufta saddozai, Performed the experiments: Yasmeen Malik, Safia 
Mustafa, Analyzed the data: Abdul Qadir, Nisar Ahmad, Contributed reagents/ materials/ analysis tools: Iftikhar Ahmed Baloch, Wrote the paper. Yasmeen Malik

\section{Reference}

1.Rashed MN (2001). Monitoring of environmental heavy metals in fish from Nasser Lake. Environ Int 27(1): 27-33.

2.Food and Agriculture Organization of the United Nations (2010) Report on the Joint FAO/WHO expert consultation on the risks and benefits of fish consumption. FAO fisheries and aquaculture Report No. 978

3.Burger J \& Gochfeld M (2005). Heavy metals in commercial fish in New Jersey. Environ Res Lett 99(3): 403-412.

4.Al-Bader N (2008). Heavy metal levels in most common available fish species in Saudi market. J Food Technol 6: 173-7.

5.Matta J, Milad M, Manger R \& Tosteson T (1999). Heavy metals, lipid peroxidation, and ciguatera toxicity in the liver of the Caribbean barracuda (Sphyraena barracuda). Biol Trace Elem Res 70(1): 69-79.

6.Gupta A, Rai DK, Pandey RS \& Sharma B (2009). Analysis of some heavy metals in the riverine water, sediments and fish from river Ganges at Allahabad. Environ Monit Assess 157(1-4): 449-458.

7.Canli M \& Atli G (2003). The relationships between heavy metal $(\mathrm{Cd}, \mathrm{Cr}, \mathrm{Cu}, \mathrm{Fe}, \mathrm{Pb}$, $\mathrm{Zn})$ levels and the size of six Mediterranean fish species. Environ Pollut 121(1): 129-136.

8.Fernandes C, Fontaínhas-Fernandes A, Cabral D \& Salgado MA (2008). Heavy metals in water, sediment and tissues of Liza saliens from Esmoriz-Paramos lagoon, Portugal. Environ Monit Assess 136: 267-275.

9.Khattak M I \& Jabeen R (2012). Detection of heavy metals in leaves of Melia azedarach and Eucalyptus Citriodora as biomonitoring tools in the region of Quetta valley. Pakistan Journal of Botany 44(2): 675-681.
10. Jhingran AG \& Talwar PK (1991). Inland fisheries of India and adjacent countries. Oxford and IBH publishing co. Pvt. Calcutta 1: 514.

11. Jayaram KC (1999). The fresh water fishes of the Indian region. Narendra publishing house, New Delhi 1: 551.

12. Poldoski JE (1980). Determination of lead and cadmium in fish and clam tissue by atomic absorption spectrometry with a molybdenum and lanthanum treated pyrolytic graphite atomizer. Anal Chem 52(7): 1147-1151.

13. Alzrog AM, Mohamed AS, Zakaria RB \& Alias AK (2013). Effect of planting media (rice husk and coco peat) on the uptake of cadmium and some micronutrients in chilli (capsicum annum 1.). Pure Appl Bioy 2(3):76.

14. Khan MJ, Achakzai AK, Iqbal Y, Ullah W, Khan N, Sharif M, Afzal M, Bazai ZA \& Ullah F (2015). Heavy metals status of the urban and agricultural soils of Peshawar, Pakistan. Pure Appl Bio 4(3): 418.

15. Sultana S, Sultana T \& Jabeen F (2015) Accumulation of heavy metals $(\mathrm{Cu}, \mathrm{Zn}$, $\mathrm{Ni}, \mathrm{Cd}, \mathrm{Co}, \mathrm{Pb}$ and $\mathrm{Cr}$ ) in blood of freshwater turtles from Balloki headworks and Trimmu barrage, Punjab, Pakistan. Pure Appl Bio 4(3): 280.

16. Findık Ö \& Çiçek E (2011). Metal concentrations in two bioindicator fish species, Merlangius merlangus, Mullus barbatus, captured from the West Black Sea Coasts (Bartin) of Turkey. Bull Environ Contam Toxicol 87(4): 399-403.

17. Dural M, Göksu, MZL \& Özak AA (2007). Investigation of heavy metal levels in economically important fish species captured from the Tuzla lagoon. Food chem 102(1): 415-421.

18. Afshan S, Ali S, Ameen US, Farid M, Bharwana SA, Hannan F \& Ahmad R (2014). Effect of different heavy metal pollution on fish. Res $J$ Chem and Environ Sci 2(1): 74-9.

19. Rajkowska M \& Protasowicki M (2013). Distribution of metals (Fe, Mn, $\mathrm{Zn}, \mathrm{Cu}$ ) 
in fish tissues in two lakes of different trophy in Northwestern Poland. Environ monitoring and assessment 185(4): 3493-3502.

20. Chi QQ, Zhu GW \& Langdon A (2007). Bioaccumulation of heavy metals in fishes from Taihu Lake, China. $J$ Environ Sci 19(12): 1500-1504.

21. Rauf A, Javed M \& Ubaidullah M (2009). Heavy metal levels in three major carps (Catla catla, Labeo rohita and Cirrhina mrigala) from the river Ravi, Pakistan. Kidney 2(1.25b): 4-43.

22. Romeo M, Siau Y, Sidoumou Z \& Gnassia-Barelli M (1999). Heavy metal distribution in different fish species from the Mauritania coast. Sci Total Environ 232(3): 169-175.

23. Zhao S, Feng C, Quan W, Chen X, Niu J \& Shen Z (2012). Role of living environments in the accumulation characteristics of heavy metals in fishes and crabs in the Yangtze River Estuary, China. Marine pollut bull 64(6): 11631171.

24. Avenant-Oldewage A \& Marx HM (2000). Bioaccumulation of chromium, copper and iron in the organs and tissues of Clarias gariepinus in the Olifants River, Kruger National Park. WATER SA-PRETORIA 26(4): 569-580.

25. Tanee T, Chaveerach A, Narong C, Pimjai M, Punsombut P \& Sudmoon R (2013). Bioaccumulation of heavy metals in fish from the Chi River, Maha Sarakham Province, Thailand. Int J Biosci 3(8): 159-167.

26. Öztürk M, Özözen G, Minareci O \& Minareci E (2009). Determination of heavy metals in fish, water and sediments of Avsar Dam Lake in
Turkey. J Environ Health Sci Eng 6(2): 73-80.

27. Dessuy MB, Vale MG R, Welz B, Borges AR, Silva MM \& Martelli PB (2011). Determination of cadmium and lead in beverages after leaching from pewter cups using graphite furnace atomic absorption spectrometry. Talanta $85(1)$ : 681-686.

28. Rezende HC, Nascentes CC \& Coelho NM (2011). Cloud point extraction for determination of cadmium in soft drinks by thermospray flame furnace atomic absorption spectrometry. Microchem Res 97(2): 118-121.

29. Méndez JÁ, García JB, Crecente RMP, Martín SG \& Latorre CH (2011). A new flow injection preconcentration method based on multiwalled carbon nanotubes for the ETA-AAS determination of $\mathrm{Cd}$ in urine. Talanta 85(5): 2361-2367.

30. Verougstraete V, Lison D \& Hotz P (2003). Cadmium, lung and prostate cancer: a systematic review of recent epidemiological data. $J$ toxic and Environ Health 6(3): 227-256.

31. Storelli MM, Storelli A \& Marcotrigiano GO (2001). Heavy metals in the aquatic environment of the Southern Adriatic Sea, Italy: macroalgae, sediments and benthic species. Environ Int 26(7): 505509.

32. EPA (2013). Consumer Factsheet on: COPPER. Retrieved on March 25, 2013 from

http://water.epa.gov/drink/contaminants/ index.cfm.

33. USEPA (1999). Technologies and costs for removal of arsenic from drinking water. Draft report, EPA-815-R-00012, Washington, DC. 